\title{
Pelatihan pidato bahasa Inggris menggunakan metode CLT pada siswa SMP/MTS Desa Ciakar
}

\author{
Shinta Nurul Inayah ${ }^{1}$, Mawi Khusni Albar ${ }^{2}$ \\ ${ }^{1}$ Tadris Bahasa Inggris, Fakultas Tarbiyah dan Ilmu Keguruan, IAIN Purw okerto \\ 2Pendidikan Agama Islam, Fakultas Tarbiyah dan Ilmu Keguruan, IAIN Purwokerto
}

1817404086@mhs.iainpurwokerto.ac.id

$\begin{array}{ccc}\text { First received: } & \text { Revised: } & \text { Final Accepted: } \\ 05 \text { Oktober } 2021 & 25 \text { Oktober } 2021 & 26 \text { Oktober } 2021\end{array}$

\begin{abstract}
Abstrak
Pidato dalam bahasa Inggris merupakan salah satu cara untuk meningkatkan kemampuan berbicara siswa dalam bahasa Inggris. Pelatihan ini dilaksanakan sebagaibentuk pengabdian kepada masyarakat dalam bidang pendidikan. Penelitian ini bertujuan untuk meningkatkan kemampuan siswa dalam berbahasa Inggris, mempersiapkan siswa untuk menghadapi perkembangan bahasa Inggris di era globalisasi, melatih kepercayaan diri siswa saat berbicara bahasa Inggris, dan mempersiapkan sisw a untuk mengikuti lomba-lomba pidato (speech) bahasa Inggris untuk meningkatkan reputasi sekolah dan prestasi dalam kemampuan penguasaan bahasa Inggris yang di miliki oleh sisw a. Jenis penelitian ini adalah investigasi yang menggunakan pendekatan kualitatif dengan metode PAR (Participatory Action Research) dan metode deskriptif. Hasil penelitian menunjukkan bahwa dengan menggunakan metode Communicative Language Teaching (CLT) dapat meningkatkan kemampuan berbicara siswa dalambahasa Inggris khususnya dalam pidato bahasa Inggris, kemudianjuga meningkatkan motivasi dan minat siswa dalam belajar pidato bahasa Inggris, serta meningkatkan pemahaman sisw a tentang pentingny a peranan pidato bahasa Inggris dan juga meningkatkan kemampuan siswa dalam memahami makna kata dalam bahasa Inggris.

Kata Kunci: Pidato Bahasa Inggris, Pengajaran Bahasa Komunikatif, Kemampuan Berbicara Bahasa Inggris, Communicative Language Teaching
\end{abstract}

\begin{abstract}
Speech in English is one way that can improve students' ability to speak English. This training is carried out as a form of education to the community in the field of education. This research aims to improve students' English language skills, prepare students to face the development of English in the era of globalization, train students' confidence when speaking English, and prepare students to participate in English speech competitions to improve the school's reputation and achievement in English mastery skills possessed by students. This type of research is research that uses a qualitative approach with PAR (Participatory Action Research) methods and descriptive methods. The results showed that using communicative language teaching (CLT) methods can improve students' speaking skills in English, especially in English speech, it also increases students' motivation and interest in learning English speech, as well as improving students' understanding of the importance of the role of English speech and also improving students' ability to understand the meaning of words in English.
\end{abstract}


Pelatihan Pidato Bahasa... - Shinta Nurul Inayah \& Mawi Khusni Albar

Keywords: English Speech, Communicative Language Teaching, English Speaking Ability, Communicative Language Teaching

\section{PENDAHULUAN}

Peranan bahasa Inggris di era globalisasi dinilai sangat penting dan menjadi prioritas dalam pembelajaran, mengingat bahasa Inggris merupakan bahasa internasional yang paling banyak digunakan di seluruh dunia. Dengan penguasaan bahasa Inggris yang baik dapat membuka banyak peluang, misalnya dalam dunia pendidikan dan dunia pekerjaan, terutama dalam hal menghadapi perkembangan ekonomi di Eropa. Namun karena adanya pandemi COVID-19 yang mengharuskan proses pembelajaran dilaksanakan secara daring, tentunya memberikan dampak pada pembelajaran bahasa Inggris. Di samping itu, pengenalan pembelajaran bahasa Inggris harus dimulai sejak dini. Maka salah satu upaya untuk meningkatkan kemampuan bahasa Inggris pada siswa tingkat SMP/MTS yang ada di desa Ciakar dan sebagai salah satu bentuk pengabdian di desa Ciakar diadakan pelatihan pidato bahasa Inggris untuk siswa tingkat SMP/MTS.

Desa Ciakar merupakan salah satu desa yang berada di kecamatan Panongan, kabupaten Tangerang, Provinsi Banten. Desa Ciakar termasuk dalam kategori desa swasembada, yaitu desa yang maju dan berkembang. Dalam bidang pendidikan desa Ciakar sudah memiliki fasilitas yang memadai, namun berdasarkan pengamatan peneliti dalam pembelajaran bahasa Inggris terutama saat proses pembelajaran daring tidak sedikit siswa yang mengalami kendala dalam pembelajaran bahasa Inggris khususnya dalam kemampuan pidato (speech) bahasa Inggris. Sangat penting bagi siswa dalam menguasai bahasa Inggris, terutama untuk meningkatkan kepercayaan diri siswa dalam menggunakan bahasa Inggris saat berada di depan umum. Kegiatan pelatihan pidato bahasa Inggris pada siswa tingkat SMP/MTS di desa Ciakar bertujuan untuk meningkatkan kemampuan bahasa Inggris siswa, mempersiapkan siswa untuk menghadapi perkembangan bahasa Inggris di era globalisasi, melatih kepercayaan diri siswa saat berbicara bahasa Inggris, dan mempersiapkan siswa untuk mengikuti lomba-lomba pidato (speech) bahasa Inggris untuk meningkatkan reputasi sekolah dan prestasi dalam kemampuan penguasaan bahasa Inggris yang di miliki oleh siswa.

Pelatihan pidato (speech) bahasa Inggris di desa Ciakar dilaksanakan secara luring atau tatap muka, tetapi sangat menerapkan protokol kesehatan dan peserta yang hadir dibatasi. Dalam pelaksanaan pelatihan pidato (speech) menggunakan metode Communicative Language Teaching (CLT). Menurut Dannish (2016) tujuan dari metode Communicative Language Teaching (CLT) diantaranya bahasa dapat menjadi alat komunikasi yang digunakan oleh siswa, bahasa digunakan agar siswa mengungkapkan ekspresi-ekspresi dalam berkomunikasi. Metode pembelajaran Communicative Language Teaching (CLT) merupakan metode yang mengedepankan penguasaan struktur bahasa dan penguasaan komunikasi secara bersamaan. Maka dengan adanya pelatihan pidato bahasa Inggris menggunakan metode Communicative Language Teaching (CLT) bertujuan untuk meningkatkan kemampuan bahasa Inggris pada siswa yang ada di desa Ciakar.

Berdasarkan penelitian terdahulu yang diteliti oleh Iwan Budiarso di SMK dan SMP Islam Mandiri Bojong Gede Bogor dengan judul penelitian "Analisis Metode Communicative 
Language Teaching Terhadap Kemampuan Berbicara Bahasa Inggris Guru-Guru SMK dan SMP Islam Mandiri Bojong Gede Bogor". Hasil observasi tersebut menjelaskan bahwa ada peningkatan kemampuan komunikasi dalam bahasa Inggris yang ditunjukkan pada nilai rata-rata, guru dapat meningkatkan kemampuan dalam memahami arti yang dimaksud dalam sebuah percakapan dalam bahasa Inggris, tergantung pada konteks dan fungsi penggunaannya dalam kehidupan sehari-hari, Communicative Language Teaching (CLT) telah berhasil meningkatkan motivasi guru serta kreativitas guru dalam proses belajar mengajar, dan guru-guru mampu menggali keterampilan berkomunikasi menggunakan bahasa Inggris dengan semangat, aktif, dan dapat berkreativitas. Maka, dalam observasi tersebut membuktikan bahwa Communicative Language Teaching (CLT) dapat digunakan secara efektif sebagai metode pembelajaran berbicara bahasa Inggris.

Dari penjelasan diatas, peneliti tertarik untuk mengadakan penelitian dan pelatihan pidato bahasa Inggris dengan menggunakan metode Communicative Language Teaching (CLT) pada siswa tingkat SMP/MTS yang berada di desa Ciakar. Metode penelitian yang digunakan dalam penelitian ini yaitu pendekatan kualitatif dengan metode deskriptif. Dengan adanya pelatihan ini diharapkan dapat meningkatkan pengetahuan serta pengalaman siswa mengenai bahasa Inggris khususnya dalam kemampuan pidato secara komunikatif, dan dapat membantu siswa ketika membuat naskah pidato bahasa Inggris secara baik dan benar dengan penggunaannya. Dan dengan adanya penelitian ini diharapkan dapat menjadi referensi bagi peneliti yang akan datang yang mengkaji bahasan yang sama, serta penelitian ini diharapkan dapat menjadi bentuk pengabdian dalam bidang pendidikan pada masyarakat desa Ciakar.

\section{METODE}

Metode yang digunakan dalam kegiatan pengabdian kepada masyarakat adalah metode deskriptif dan metode PAR (Participatory Action Research) dengan menggunakan pendekatan kualitatif. Menurut Sugiyono (2009) metode deskriptif adalah metode yang berfungsi untuk menggambarkan atau menganalisis suatu penelitian tetapi tidak digunakan untuk membuat kesimpulan yang lebih luas. Sedangkan pengertian tentang metode PAR (Participatory Action Research) menurut Yoland Wadworth adalah suatu penelitian yang melibatkan adanya partisipasi yang menyebabkan aksi dengan memuat paradigma dalam ilmu yang baru dan paradigma pada pengetahuan kuno atau terdahulu. Kemudian, metode deskriptif menurut Kuncoro (2009) penelitian deskriptif adalah kegiatan mengumpulkan data guna menjawab pertanyaan terkait permasalahan yang dikaji dalam penelitian.

Data penelitian yang diambil oleh peneliti didapatkan selama tiga pertemuan dalam tiga Minggu. Adapun metode yang digunakan peneliti mengadopsi konsep berpikir yang dikemukakan oleh Richards, yang terbagi dalam tiga langkah, yaitu sebagai berikut:

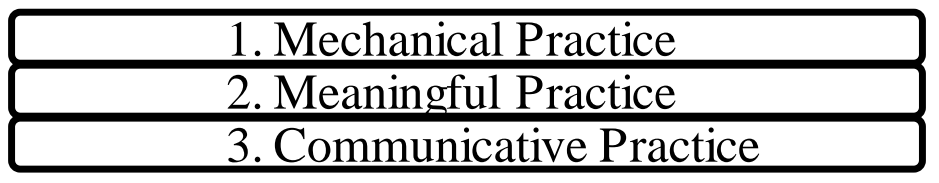




\section{Mechanical Practice}

Di tahap pertama peneliti mengadakan pertemuan pertama dengan menyediakan dan menjelaskan beberapa materi. Materi tersebut diawali dengan pengenalan pengertian pidato bahasa Inggris dan pentingnya pidato bahasa Inggris, hal ini dilakukan untuk menumbuhkan rasa semangat, rasa ingin tahu siswa, dam motivasi siswa dalam mempelajari pidato bahasa Inggris. Materi selanjutnya peneliti menyampaikan struktur pidato yang terdiri dari pembukaan, isi, dan penutupan, hal tersebut dilakukan guna memberikan gambaran lebih lanjut tentang struktur yang ada di dalam pidato. Kemudian, materi yang selanjutnya yaitu menyampaikan vocabulary atau kosa kata yang ada di dalam pembukaan pidato bahasa Inggris dan memberikan contoh pembukaan pidato yang baik dan benar menggunakan bahasa Inggris. Selanjutnya, setelah peneliti menyampaikan materi dan siswa mengamati materi yang di sampaikan, peneliti meminta siswa untuk mempraktikkan penyampaian pembukaan pidato bahasa Inggris secara mandiri, hal tersebut dilaksanakan untuk menganalisis apakah materi dan contoh yang disampaikan oleh peneliti dapat diterima dengan baik oleh siswa dan juga untuk menganalisis kemampuan siswa pada saat sebelum dilaksanakannya pelatihan sampai sesudah dilaksanakannya pelatihan pada pertemuan pertama.

\section{Meaningful Practice}

Tahap meaningful practice dilaksanakan pada Minggu kedua dan pertemuan kedua. Pada pertemuan ini hal yang ditekankan adalah pembahasan mengenai bagian isi dari pidato bahasa Inggris. Tahap ini diawali dengan mereview materi Minggu lalu atau pertemuan pertama, agar siswa tidak lupa dan memastikan materi yang disampaikan pada Minggu pertama dapat bermakna bagi siswa. Pada tahap meaningful practice, materi yang disampaikan peneliti yaitu kata kerja (verb), kata benda (noun), kata sifat (adjective), maupun fungsi kelas kata lainnya yang berhubungan dan umumnya sering digunakan pada saat menyampaikan isi pidato dalam bahasa Inggris. Kemudian, peneliti juga memberikan contoh bagaimana penyusunan teks isi pidato bahasa Inggris lalu mempraktekkannya di depan siswa. Setelah itu, peneliti meminta siswa untuk mempraktekkan penyampaian isi pidato bahasa Inggris yang baik dan benar.

\section{Communicative Practice}

Tahap ini dilaksanakan pada Minggu ketiga dan pertemuan ketiga. Peneliti menyampaikan materi tentang bagaimana cara dan hal-hal yang harus diperhatikan saat menutup pidato dalam bahasa Inggris. Namun pada tahap ini yang lebih ditekankan adalah praktik pidato bahasa Inggris dari pembukaan, isi, dan juga penutupan yang dilakukan oleh siswa. Praktik tersebut harus dilaksanakan secara interaktif atau menciptakan pidato yang dapat menjalin komunikasi dengan baik antara pembicara dengan pendengar. Siswa diminta untuk mempraktikkan secara individu hal yang sudah dipelajarinya dari pertemuan pertama, kedua, dan ketiga. Ketika ada siswa yang sedang mempraktekkan, siswa yang lainnya harus memperhatikan dan berperan sebagai pendengar, kemudian di akhir setiap siswa harus memberikan tanggapan tentang penampilan masing-masing siswa. Dan siswa juga di minta untuk mengeksplorasikan dan melakukan improvisasi dalam penyusunan naskah pidato dan juga saat penyampaian pidato. 
Dalam penelitian ini, peneliti menggunakan beberapa kajian pustaka yang relevan dengan judul penelitian. Kajian pustaka yang mendukung penelitian ini adalah sebagai berikut:

\section{Pidato (Speech)}

Menurut kamus Oxford Dictionary (2000: 1292), pidato merupakan suatu pembicaraan yang resmi disampaikan oleh seseorang yang menyampaikan pesan atau amanah kepada peserta yang hadir di suatu forum. Kemudian, Barret dalam Raudatul (2009: 12) menjelaskan bahwa pidato merupakan kegiatan perorangan yang praktis. Selanjutnya Flether dalam Niki (2007: 11) menerangkan bahwa pidato adalah langkah untuk mengungkapkan atau menyampaikan ide-ide, fakta-fakta, dan mengekspresikan perasaan, atau dengan kata lain pidato adalah salah satu kegiatan untuk mempengaruhi pendengar. Maka dapat disimpulkan bahwa pidato merupakan salah satu kegiatan berbicara dimana pembicara menyampaikan suatu informasi secara jelas kepada pendengar atau lawan bicara yan g berfungsi untuk mempengaruhi atau mengubah sikap atau perilaku pendengar melalui informasi dan ide yang telah disampaikan oleh pembicara.

Menurut Dale dan Wolf (2000: 35) dalam sebuah pidato minimal harus memiliki 3 komponen, yaitu: a. An attention getting opener dimana pada awal atau saat pembukaan pidato, pembicara harus memperoleh perhatian pendengar sehingga pendengar akan tertarik mendengarkan pidato yang disampaikan pembicara. b. $A$ preview of the body, yaitu cara untuk memperkenalkan topik atau isi pidato kepada pendengar, isi pidato harus mempertimbangkan 4 hal yang berhubungan dengan topik yang disampaikan, yaitu 1) Memecah bagian-bagian topik, hal ini bertujuan untuk mempermudah pembicara dalam menyampaikan ide-ide dalam pidato. 2) Mempersempit bagian topik pidato, ini berfungsi agar topik yang dibahas oleh pembicara tidak keluar dari bahasan tertentu yang akan dikembangkan oleh pembicara. 3) Menyusun bagian topik secara benar, hal ini akan membantu pembicara untuk menyampaikan ide-ide yang telah disusun. 4) Mengembangkan topik dengan memberikan informasi terbaru, bukti nyata, dan dengan alat peraga. c. Kesimpulan pidato, harus terdiri dari ringkasan ide utama dan kalimat penutup untuk mengakhiri pidato.

Sementara menurut Carlie dan Daniel (2008: 113) menjelaskan bahwa ada 8 bagian dari komponen pidato, yaitu: 1) Menyatakan ide pokok pidato secara jelas. 2) Membuat bahasan yang menarik agar pendengar tertarik mendengarkan pidato, dan sampaikan alasan mengapa topik tersebut sangat penting bagi pendengar. 3) Menjelaskan pengaruh keadaan sekarang terhadap topik tersebut, serta berikan gambaran, contoh, kenyataan, dan pendapat para ahli yang dapat mendukung topik pidato. 4) Menjelaskan apa saja faktor-faktor yang dapat mempengaruhi topik tersebut, jelaskan contoh, fakta, uraian, dan pendapat para ahli. 5) Sampaikan solusi dari permasalahan atau bahasan dalam pidato secara sistematis. 6) Memberikan solusi dalam permasalahan tersebut secara terperinci. 7) Meyakinkan pendengar bahwa apa yang kita sampaikan dapat bermanfaat bagi pendengar. 8) Simpulan pidato dengan memberikan kalimat penutup. 


\section{Communicative Language Teaching (CLT)}

Pengertian metode Communicative Language Teaching (CLT) menurut Littlewood (2002: 1) "One of the most characteristic features of communicative language teaching is that it pays systemic attention to functional as well as structural aspects of language, combining these into a more fully communicative view." Maka Communicative Language Teaching (CLT) merupakan metode pembelajaran bahasa yang harus dipelajari secara bersamaan antara keterampilan dalam struktur bahasa dan keterampilan saat berkomunikasi.

Menurut Johnson, K dan Johnson, H (1998) terdapat 5 karakteristik penerapan Communicative Language Teaching (CLT), karakteristik tersebut, yaitu : a. Appropriateness, yaitu bahasa yang digunakan harus diterapkan dengan baik dan benar sesuai dengan konteks penggunaannya, baik pada segi formalitas maupun kondisi yang sedang dibahas.b. Message focus, perpindahan informasi dalam proses pembelajaran tentang pemahaman makna bahasa tentang makna sebenarnya. c. Psycholinguistic processing, merupakan proses kemampuan kognitif dalam memperoleh dan menguasai bahasa. d. Risk taking, yaitu siswa dapat mempelajari kesalahan berbahasa dengan mengatasinya menggunakan berbagai strategi. e. Free practice, yaitu berlatih kemampuan berbahasa dalam penggunaan hal yang sudah dipelajari dalam proses pembelajaran bahasa.

Selanjutnya Richards dan Rodgers (2001: 172) menjelaskan terdapat 5 prinsip yang terkandung dalam metode Communicative Language Teaching (CLT), diantaranya sebagai berikut: a. Learners learn a language through using it to communicative, yaitu siswa mempelajari bahasa kemudian digunakannya sebagai sarana untuk komunikasi. b. Authentic and meaningful communication should be the goal of classroom activities, yaitu kegiatan pembelajaran bahasa yang ada di dalam kelas memiliki tujuan keotentikan dan kebermaknaan dalam berkomunikasi. c. Fluency is an important dimension of communication, yaitu dalam berkomunikasi menggunakan bahasa kelancaran menjadi dimensi yang penting. d. Communication involves the integration of different language skills, yaitu dalam berkomunikasi mencangkup konsolidasi pada 4 keterampilan yang ada dalam mempelajari bahasa. e. Learning is a process of creative construction and involves trial and error, yaitu proses pembelajaran merupakan suatu cara untuk membangun kreativitas yang melibatkan melakukan percobaan dan adanya suatu kesalahan.

Richards dan Rodgers juga menjelaskan bahwa penerapan metode Communicative Language Teaching (CLT) dibagi menjadi 3 peran, yaitu learner roles, teacher roles, dan the roles of materials. Pertama, learner roles yaitu siswa harus mampu berpartisipasi secara matang atau berkelanjutan di dalam perjalanan kegiatan belajar mengajar. Maka tujuan dalam pembelajaran yang dicapai dengan menggunakan metode Communicative Language Teaching (CLT) tergantung kepada kemampuan masing-masing siswa. Kedua, teacher roles yaitu guru menjadi peran utama untuk menganalisis kebutuhan peserta didik dan guru harus mencari tahu permasalahan yang dialami siswa saat kegiatan pembelajaran berlangsung. Kemudian peran guru sebagai konselor bagi peserta didiknya yang harus memahami situasi dan kondisi 
yang terjadi pada peserta didik serta guru juga harus membantu peserta didik dalam mencarikan solusi. Ketiga, the roles of materials, yaitu materi-materi yang bisa digunakan pada metode Communicative Language Teaching (CLT) merupakan textbased materials dan realita.

Kemudian Richards membagi tahapan pembelajaran yang menggunakan metode Communicative Language Teaching (CLT) pada 3 wujud kegiatan pelatihan, yaitu mechanical practice, meaningful practice, dan communicative practice. (1) Mechanical practice, yaitu tahap dimana siswa memiliki kesempatan lebih untuk dapat mengekspresikan kemampuan bahasanya tanpa sepenuhnya memahami fungsi bahasa yang mereka gunakan, pelatihan dalam tahap ini berupa bentuk motivasi, pengetahuan secara umum, dan latihan pengulangan tata bahasa. (2) Meaningful practice, pada tahap ini siswa bisa menentukan penggunaan struktur bahasa yang benar dan sesuai dengan fungsi, konsep, dan konteks penggunaannya. (3) Communicative practice, di tahap kali ini proses pembelajaran bahasa berfokus dalam penerapan bahasa di dalam konteks komunikasi secara nyata

Menurut hasil penelitian yang dilakukan oleh George M. Jacobs dan Thomas S.C. Farell di tahun 2003 yang berjudul "Understanding and Implementing the CLT paradigm" penelitian tersebut menunjukkan bahwa ada peningkatan yang signifikan dalam proses pembelajaran bahasa asing yaitu bahasa Inggris pada saat belajar dan mengajar. Kemudian, hasil penelitian yang dilakukan oleh Ming Chang yang berjudul "EFL Teacher's Attitudes towards Communication Language Teaching in Taiwanese College" pada tahun 2011, menjelaskan pada guru terdapat adanya kenyamanan dan efisiensi dalam belajar bahasa Inggris pada saat menerapkan metode Communicative Language Teaching (CLT) pada pelaksanaan pembelajaran. Selanjutnya, berdasarkan penelitian yang telah dilakukan oleh Saeed Ahmad dan Congman Rao yang berjudul "Applying Communicative Approach in Teaching English as a Foreign Language: a Case Study of Pakistan" hasil penelitiannya menyatakan bahwa siswa di Pakistan yang mempelajari bahasa termotivasi oleh guru-gurunya lebih antusias selama berlangsungnya proses belajar mengajar bahasa Inggris dengan menggunakan metode Communicative Language Teaching (CLT).

\section{HASIL DAN PEMBAHASAN}

Hasil serta pembahasan yang didapatkan dari penelitian sebagai bentuk pengabdian menunjukkan bahwa dalam proses belajar pidato (speech) bahasa Inggris yang termasuk dalam keterampilan berbicara (speaking) harus berintegrasi pada kemampuan bahasa yang lainnya juga, seperti keterampilan mendengarkan (listening), menulis (writing), dan membaca (reading). Dalam pelaksanaan belajar pidato (speech) bahasa Inggris diperlukan proses persiapan yang sistematis dan matang, yaitu peneliti harus menentukan metode pembelajaran dan strategi pembelajaran yang dapat memenuhi kebutuhan para siswa. Hal ini dikarenakan setiap siswa memiliki latar belakang yang berbeda, untuk mengatasi hal tersebut metode yang digunakan dalam proses pembelajaran haruslah interaktif, yaitu dengan menerapkan metode 
Communicative Language Teaching dengan menyampaikan dan menjelaskan materi tentang pidato (speech) dalam bahasa Inggris secara komunikatif.

Metode Communicative Language Teaching dapat dikategorikan ke dalam metode pembelajaran yang efisien sebagai upaya meningkatkan keterampilan berbicara siswa dalam bahasa Inggris, khususnya dalam pidato bahasa Inggris. Dengan men erapkan metode Communicative Language Teaching dapat memberikan pemahaman yang lebih terhadap meningkatnya kemampuan berbicara siswa dalam bahasa Inggris tentunya juga sesuai dengan makna kebahasaan yang digunakan. Kemudian, melalui metode Communicative Language Teaching memberikan inovasi baru dalam suasana pembelajaran yang dirasakan oleh siswa dalam mempelajari pidato bahasa Inggris. Selanjutnya, dengan menggunakan metode ini dapat meningkatkan motivasi, minat belajar, dan rasa ingin tahu siswa dalam proses pembelajaran pidato bahasa Inggris. Sebagai penerapannya, peneliti menganalisis terdapat kendala terbesar dalam pengajaran pidato bahasa Inggris, yaitu minimnya penggunaan bahasa Inggris dalam kehidupan sehari-hari. Hal tersebut dilatarbelakangi karena terbatasnya rasa kepercayaan diri pada sebagian besar siswa dalam berkomunikasi saat menggunakan bahasa Inggris.

Penggunaan metode Communicative Language Teaching untuk meningkatkan keterampilan siswa dalam berkomunikasi menggunakan bahasa Inggris, khususnya dalam pidato bahasa Inggris membuat siswa dapat lebih mengekspresikan dan mengeksplorasikan kemampuan berinteraksi menggunakan bahasa Inggris antara siswa satu dengan siswa lainnya. Melalui metode ini membuat kebebasan pada siswa dalam mengekspresikan dan mengeksplorasikan keterampilan berbicara dalam menggunakan bahasa Inggris, oleh karena itu dapat meningkatkan motivasi para siswa dapat secara signifikan. Sejalan dengan hal tersebut ditunjukkan karena adanya peningkatan dalam interaksi yang terjadi sesama siswa saat berpidato bahasa Inggris. Sehingga siswa dapat lebih memahami ketepatan dalam pemilihan vocabulary, pronunciation, grammatical, fluency, dan accent.

Pembelajaran berbicara bahasa Inggris dengan penerapan metode pembelajaran bahasa Inggris yang komunikatif dapat memberikan manfaat yang diwujudkan ke dalam hasil belajar. Dengan menggunakan 3 tahapan yang ada dalam metode Communicative Language Teaching, yaitu (Mechanical practice, meaningful practice, dan communicative practice) membuat suasana kelas menjadi menyenangkan karena terciptanya hubungan secara berlangsung sehingga kemampuan pidato siswa dalam bahasa Inggris dapat terus meningkat. Kemudian, rasa ingin tahu siswa juga meningkat ketika belajar dengan menerapkan metode Communicative Language Teaching, hal tersebut dikarenakan rasa antusias para siswa dalam memahami materi-materi yang diajarkan, latihan-latihan, dan juga aktivitas-aktivitas pembelajaran secara lisan dan tulisan yang dijelaskan oleh peneliti.

Dalam penelitian terdahulu yang dilakukan oleh Iwan Budiarso, dengan penelitian berjudul "Analisis Metode Communicative Language Teaching Terhadap Kemampuan Berbicara Bahasa Inggris Guru-Guru SMK dan SMP Islam Mandiri Bojong Gede" menjelaskan bahwa metode Communicative Language Teaching berhasil meningkatkan motivasi dan kreativitas guru-guru dalam berbicara menggunakan bahasa 
Inggris. Kemudian, penelitian tersebut juga menunjukkan adanya peningkatan yang signifikan dalam pelatihan berbicara bahasa Inggris menggunakan metode Communicative Language Teaching. Dengan meningkatnya kemampuan guru dalam berkomunikasi menggunakan bahasa Inggris tentunya akan memberikan dampak positif bagi proses belajar bahasa Inggris yang akan dilaksanakan oleh guru-guru tersebut.

Adapun hasil dari pelatihan pidato bahasa Inggris menggunakan metode Communicative Language Teaching yang dilaksanakan di desa Ciakar pada siswa tingkat SMP/MTS dapat digambarkan melalui kalkulasi nilai selama 3 pertemuan yang tersedia pada tabel berikut ini:

Tabel 1: Kalkulasi Nilai Siswa Dalam Pelatihan Pidato Bahasa Inggris

\begin{tabular}{cccc}
\hline $\begin{array}{c}\text { Nomor } \\
\text { Urut Siswa }\end{array}$ & $\begin{array}{c}\text { Pertemuan I } \\
\text { (Mechanical Practice) }\end{array}$ & $\begin{array}{c}\text { Pertemuan II } \\
\text { (Meaningful Practice) }\end{array}$ & $\begin{array}{c}\text { Pertemuan III } \\
\text { (Communicative } \\
\text { Practice) }\end{array}$ \\
\hline 1. & 64 & 69 & 76 \\
\hline 2. & 72 & 76 & 82 \\
\hline 3. & 62 & 64 & 70 \\
\hline 4. & 68 & 74 & 78 \\
\hline 5. & 74 & 78 & 84 \\
\hline
\end{tabular}

Pada tabel diatas, dapat terlihat bahwa ada peningkatan nilai dari dari setiap pertemuan dan satu pertemuan terdiri dari satu tahapan. Nilai yang tertera diatas merupakan nilai rata-rata dari hasil kalkulasi nilai tentang, vocabulary, pronunciation, flueny, accent, dan grammar. Pada pertemuan pertama yaitu pada tahap Mechanical Practice merupakan nilai kemampuan dasar pidato dalam bahasa Inggris siswa di bagian pembukaan pidato. Kemudian, pada pertemuan kedua yaitu pada tahap Meaningful Practice latihan sudah mulai dilakukan secara terkontrol dan lebih terperinci membahas bagian isi dalam pidato bahasa Inggris. Selanjutnya pada pertemuan ketiga pada tahap Communicative Practice merupakan nilai dari hasil improvisasi dan eksplorasi kemampuan siswa dalam berpidato bahasa Inggris dari bagian pembukaan, isi, dan penutupan.

\section{KESIMPULAN}

Dari hasil penelitian yang telah dilakukan di desa Ciakar pada siswa tingkat SMP/MTS dalam upaya meningkatkan kemampuan siswa dalam berbicara bahasa Inggris menggunakan metode Communicative Language Teaching menunjukkan adanya peningkatan yang signifikan. Hal tersebut dapat di lihat dari tabel kalkulasi nilai dari pertemuan I, II dan III. Dengan menggunakan metode Commutative Language Teaching dapat meningkatkan kemampuan siswa dalam berbicara bahasa Inggris, khususnya pada saat pidato bahasa Inggris, hal tersebut terlihat dalam menerapkan tahap mechanical practice, meaningful practice, dan communicative practice. Sehingga dengan menggunakan metode ini dapat juga meningkatkan pemahaman siswa dalam memahami makna kata yang ada dalam bahasa Inggris, serta dapat meningkatkan motivasi siswa dalam belajar bahasa Inggris. 


\section{UCAPAN TERIMAKASIH}

Penelitian tentang pengabdian kepada masyarakat yang telah dilaksanakan di desa Ciakar dapat berjalan dengan baik karena adanya bantuan dari berbagai pihak. Oleh karena itu, peneliti mengucapkan banyak terima kasih kepada kepala desa di desa Ciakar, seluruh ketua RT di desa Ciakar, seluruh masyarakat desa Ciakar yang telah membantu berpartisipasi dalam pelatihan pidato bahasa Inggris dan juga kedua orang tua peneliti yang selalu membantu secara materi dan juga moral. Tanpa bantuan dari berbagai pihak tersebut, tentunya kegiatan dan penelitian pelatihan pidato bahasa Inggris di desa Ciakar tidak dapat berjalan dengan baik.

\section{DAFTAR PUSTAKA}

Budiarso, Iwan. 2019. "Analisis Metode Communicative Language Teaching Terhadap Kemampuan Berbicara Bahasa Inggris Guru-Guru SMK Dan SMP Islam Mandiri Bojong Gede Bogor". Jurnal SAP. Vol 3(3). (PDF) Analisis Metode Communicative Language Teaching terhadap Kemampuan Berbicara Bahasa Inggris Guru-Guru SMK dan SMP Islam Man diri Bojong Gede Bogor (researchgate.net)

Chang, Ming. 2011. "EFL Teacher's Attitudes towards Communication Language Teaching in Taiwanese College". Asian EFL Journal. Vol 53 Microsoft Word - Volume 53 CEBU Issue 2011 Robert (asian-efl-journal.com)

Dale. Wolf. 2000. "Speech Communication Made Simple a Multicultural Perpective". New York: Longman.

Febriyanti, Husnaini, Rina. 2017. "Pengunaan Metode Communicative Language Teaching Dalam Pengajaran Bahasa Inggris Pada Guru Tutor Di Bimbingan Belajar". Jurnal Ilmiah Kependidikan. Vol 4(3). https://core.ac.uk/download/pdf/276616708.pdf

J.C, Ricard., T.S, Rodgers. 2001. "Approaches and Methods in Language Teaching (Second Edition)". Cambridge: Cambridge University Press. Marketing Fragment $6 \mathrm{x}$ 10.5.T65 (cambridge.org)

Johnson, K., Jonshon, H. 1998. "Communicative Methodology in K. Johnson and H. Johnson". Encylipedic Dictionary of Applied Linguistics. Oxford: Blackwell.

Littlewood, William. 2002. "Communicative Language Teaching". Cambridge: Cambridge University Press.

M.G, Jacobs., C.S.T, Farrell. 2003. “Understanding and Implementing the CLT (Communicative Language Teaching) Paradigm". RELC Journal. 34(1). Jacobs, G (ed.gov)

Mudrajat, Kuncoro. 2003. “Metode Riset untuk bisnis dan Ekonomi. Jakarta: Erlangga.

Samad, Ghazali, Ahmad. Wahyuni, Sri. 2019. “Peningkatan Kompetensi Siswa Sekolah Dasar Melalui Program Pelatihan Pidato Bahasa Inggris Berbasis Games, Dan 
Meaningful Practices Dengan Pendekatan Students Centered Learning". Jurnal Pengabdian Kepada Masyarakat Sosiosaintifik. Vol 1(1). https://www.bing.com/search?q=Peningkatan+Kompetensi+Siswa+Sekolah+Dasar + Melalui+Program+Pelatihan+Pidato+Bahasa+Inggris+Berbasis+Games $\% 2 \mathrm{C}+$ Dan + Meaningful+Practices+Dengan+Pendekatan+Students+Centered+Learning\&qs=n\&f orm $=$ QBRE\&sp $=-$

$1 \&$ pq=peningkatan+kompetensi+siswa+sekolah+dasar+melalui+program+pelatiha $\underline{\mathrm{n}+\text { pidato+bahasa+ing gris+berbasis }+ \text { games } \% 2 \mathrm{C}+\text { dan }+ \text { meaningful+practices }+ \text { dengan }}$ + pendekatan+students+centered+learning $\& s c=0$ 176\&sk=\&cvid=BB8CE4BA11BB4608AB56BB8B2FD1496E

Saputra, Riyadi. 2018. "Analisis Kemampuan Berpidato Bahasa Inggris Siswa Tingkat SMA/MA SeKabupaten Dharmasraya". Vol 2(10).

Sugiyono. 2009. "Metode Penelitian Kuantitatif dan Kualitatif". Bandung: CV Alfabeta Wadworth, Yoland. bab 2.pdf (uinsby.ac.id) 